\title{
Prevalence of dementia among elderly Brazilians: a systematic review
}

\author{
Prevalência de demência em idosos brasileiros: uma revisão sistemática
}

\author{
Susana Dytz Fagundes', Marcus Tolentino Silva", Maria Fernanda Reis Silva Thees"II, Maurício Gomes PereiralV \\ Universidade de Brasília, Brasília, Federal District, Brazil
}

KEY WORDS:

Aged.

Memory disorders.

Frail elderly.

Memory.

Dementia.

Prevalence.

\begin{abstract}
CONTEXT AND OBJECTIVE: The rapid growth of the elderly population in Brazil has implied a significant rise in the number of individuals with dementia. The real prevalence of this disease needs to be ascertained in order to establish appropriate measures for improving the quality of life of those affected. The aim of this study was to estimate the prevalence of dementia among elderly Brazilians ( $\geq 60$ years) through a systematic review of highquality, population-based, double-blind studies published between 1990 and 2010.

DESIGN AND SETIING: Systematic review of prevalence studies. The manuscript was produced in the School of Medicine, Universidade de Brasília. METHODS: Database searches for articles were conducted in Medline (Medical Literature Analysis and Retrieval System Online), Embase (Excerpta Medica database), Lilacs (Literatura Latino-Americana e do Caribe em Ciências da Saúde), SciELO (Scientific Electronic Library Online) and theses and dissertations, using specific keywords. Quality was assessed according to eight criteria for sampling and measurement of findings.

RESULTS: Out of 112 articles identified, eleven were included in the qualitative synthesis. In five higher-quality studies from São Paulo, the prevalence rates ranged from 5.1 to $19.0 \%$. No meta-analysis was presented because of heterogeneity among the studies. Poor, illiterate, female and very elderly individuals were the groups most affected.

CONCLUSION: The findings from this review did not reflect the reality of the whole country. Although the results brought some information on the prevalence and distribution of dementia in Brazil, cross-sectional studies with consistent methodology are needed.
\end{abstract}

\section{RESUMO}

\section{Idoso.}

Transtornos da memória.

Idoso fragilizado.

Memória.

Demência.

Prevalência.
CONTEXTO E OBJETIVO: 0 crescimento rápido da população idosa no Brasil implicou no aumento significativo do número de indivíduos com demência. A prevalência real da doença deve ser constatada a fim de que se possam estabelecer medidas apropriadas para melhorar a qualidade de vida das pessoas afetadas. 0 objetivo deste estudo foi estimar a prevalência de demência entre a população brasileira idosa ( $\geq 60$ anos) através da revisão sistemática de estudos populacionais, duplo-cegos, de alta qualidade, publicados entre 1990 e 2010.

TIPO DE ESTUDO E LOCAL: Revisão sistemática de estudos de prevalência. 0 manuscrito foi realizado na Faculdade de Medicina, Universidade de Brasilia.

MÉTODOS: Os artigos foram pesquisados nos bancos de dados Medline (Medical Literature Analysis and Retrieval System Online), Embase (Excerpta Medica database), Lilacs (Literatura Latino-Americana e do Caribe em Ciências da Saúde), SciELO (Scientific Electronic Library Online) e de teses e dissertações, usando-se palavras-chave específicas. A qualidade foi avaliada de acordo com oito critérios relacionados à amostragem e à mensuração dos achados.

RESULTADOS: Dentre os 112 artigos identificados, 11 foram incluídos na síntese qualitativa. Em cinco estudos de melhor qualidade realizados em São Paulo, a taxa de prevalência variou de 5,1\% a 19,0\%. A metanálise não foi realizada devido à heterogeneidade entre os estudos. Pobres, analfabetos, mulheres e pessoas de idade avançada foram os grupos mais afetados.

CONCLUSÃo: Os achados desta revisão não refletem a realidade de todo o país. Embora os resultados mostrem informações sobre a prevalência e a distribuição da demência no Brasil, estudos transversais com metodologia consistente precisam ser realizados.

\section{INTRODUCTION}

The average age of the Brazilian population is increasing rapidly, and the fastest growing sector consists of adults $\geq 80$ years of age. ${ }^{1-3}$ According to data derived from the demographic census, there were just two million elderly individuals ( $\geq 60$ years old) in Brazil in 1950, comprising $4 \%$ of the country's total population. By 2000 , this figure had risen to 14.5 million. i.e. $8.6 \%$ of the total population. It is estimated that the elderly will account for $25 \%$ of the Brazilian population by 2050 . These demographic dynamics will give rise to changes in the health profile of the population, consisting especially of increases in the prevalence of chronic degenerative diseases and physical and mental incapacities. An aging population implies intensification of the demand for social and health services. This poses a significant challenge for public policies.

Dementia is one of the most distressing health problems that affect the elderly. It destroys individuals' and families' quality of life. ${ }^{4}$ Although the problem of dementia is a matter of concern for government authorities, data relating to the prevalence of the disease in Brazil are scarce. The objective of this systematic review was to draw up a profile of the prevalence of dementia in this country.

IMD, MSc. Gynecologist and Obstetrician, Universidade Católica de Brasília, Brasília, Federal District, Brazil.

"Pharmacist. Adviser, Department of Science and Technology, Secretariat of Science, Technology and Strategic Inputs, Ministry of Health, Brasília, Federal District, Brazil.

"'Biologist. Adviser, National Health Surveillance Agency (Anvisa), Ministry of Health, Brasília, Brazil.

IVMD, PhD. Full Professor, School of Medicine, Universidade de Brasília, Federal District, Brazil. 


\section{METHODS}

\section{Electronic search and selection of articles for review}

Relevant articles published during the period 1990-2010 were retrieved from traditional electronic databases, including Medline (Medical Literature Analysis and Retrieval System Online) (via PubMed), Embase (Excerpta Medica database), Lilacs (Literatura Latino-Americana e do Caribe em Ciências da Saúde) (via Biblioteca Virtual de Saúde, BVS), SciELO (Scientific Electronic Library Online) and the Brazilian thesis database. The keywords were in Portuguese, Spanish and English and related to dementia, elderly, prevalence and Brazil (Table 1). Population-based cross-sectional studies with the use of cognitive tests to evaluate dementia among individuals $>60$ years old were included in the review. Studies were excluded if they dealt with subjects with psychiatric disorders, cognitive impairment due to congenital, neurological or infectious causes, long-term dementia or test validation. The initial selection of the articles was based on analysis of the abstracts, and was

Table 1. Full electronic search strategy

\begin{tabular}{|c|c|}
\hline Database & Search terms \\
\hline Medline & $\begin{array}{l}\text { (“Aged”[Mesh] OR Elderly OR “Aged, } 80 \text { and over”[Mesh] OR (Oldest } \\
\text { Old) OR Nonagenarians OR Nonagenarian OR Octogenarians OR Octo- } \\
\text { genarian OR Centenarians OR Centenarian) AND (“Dementia”[Mesh] } \\
\text { OR Dementias OR Amentia OR Amentias OR (Senile Paranoid Demen- } \\
\text { tia) OR (Dementias, Senile Paranoid) OR (Paranoid Dementia, Senile) } \\
\text { OR (Paranoid Dementias, Senile) OR (Senile Paranoid Dementias) OR } \\
\text { (Familial Dementia) OR (Dementia, Familial) OR (Dementias, Familial) } \\
\text { OR (Familial Dementias)) AND (“Prevalence”[Mesh] OR Prevalences) } \\
\text { AND (/Brazil) }\end{array}$ \\
\hline Embase & $\begin{array}{c}\text { \#1 'aged'/exp AND [embase]/lim } \\
\text { \#2 'dementia'/exp AND [embase]/lim } \\
\text { \#3 ‘prevalence'/exp AND [embase]/lim } \\
\text { \#4 'brazil'/exp AND [embase]/lim } \\
\text { \#5 \#1 AND \#2 AND \#3 AND \#4 }\end{array}$ \\
\hline Lilacs & $\begin{array}{l}\text { (Aged OR Elderly OR Anciano OR (Adulto Mayor) OR Idoso OR (Aged, } \\
80 \text { and over ) OR Centenarians OR Nonagenarians OR Octogenarians } \\
\text { OR (Oldest Old) OR (Anciano de } 80 \text { o más Años ) OR Centenarios } \\
\text { OR Nonagenarios OR Octogenarios OR Viejísimos OR (Anciano de } 80 \\
\text { Años o más) OR (Ancianos de } 80 \text { o más Años) OR (Ancianos de } 80 \\
\text { Años o más) OR (Ancianos de } 80 \text { Años y más) OR (Idoso de } 80 \text { Anos } \\
\text { ou mais ) OR Centenários OR Nonagenários OR Octogenários OR Vel- } \\
\text { híssimos OR (Idoso de } 80 \text { ou mais Anos) OR (Idosos de } 80 \text { ou mais } \\
\text { Anos) OR (Idosos de } 80 \text { Anos ou mais)) AND (Dementia OR (Senile } \\
\text { Paranoid Dementia) OR Demencia OR (Demencia Paranoide Senil) } \\
\text { OR Demência OR (Demência Senil Tipo Paranóide)) AND (Prevalence } \\
\text { OR (Prevalence Rate) OR Prevalencia OR (Tasa de Prevalencia) OR } \\
\text { (Coeficiente de Prevalencia) OR Prevalência OR (Taxa de Prevalência) } \\
\text { OR (Coeficiente de Prevalência)) AND (Brazil OR Brasil) }\end{array}$ \\
\hline SciELO & $\begin{array}{l}\text { (Aged OR Elderly OR Anciano OR (Adulto Mayor) OR Idoso OR (Aged, } \\
80 \text { and over ) OR Centenarians OR Nonagenarians OR Octogenarians } \\
\text { OR (Oldest Old) OR (Anciano de } 80 \text { o más Años ) OR Centenarios } \\
\text { OR Nonagenarios OR Octogenarios OR Viejísimos OR (Anciano de } 80 \\
\text { Años o más) OR (Ancianos de } 80 \text { o más Años) OR (Ancianos de } 80 \\
\text { Años o más) OR (Ancianos de } 80 \text { Años y más) OR (Idoso de } 80 \text { Anos } \\
\text { ou mais ) OR Centenários OR Nonagenários OR Octogenários OR Vel- } \\
\text { híssimos OR (Idoso de } 80 \text { ou mais Anos) OR (Idosos de } 80 \text { ou mais } \\
\text { Anos) OR (Idosos de } 80 \text { Anos ou mais)) AND (Dementia OR (Senile } \\
\text { Paranoid Dementia) OR Demencia OR (Demencia Paranoide Senil) } \\
\text { OR Demência OR (Demência Senil Tipo Paranóide)) AND (Prevalence } \\
\text { OR (Prevalence Rate) OR Prevalencia OR (Tasa de Prevalencia) OR } \\
\text { (Coeficiente de Prevalencia) OR Prevalência OR (Taxa de Prevalência) } \\
\text { OR (Coeficiente de Prevalência)) AND (Brazil OR Brasil) }\end{array}$ \\
\hline $\begin{array}{l}\text { Brazilian thesis } \\
\text { database }^{*}\end{array}$ & $\begin{array}{c}\text { Demência } \\
\text { Filters: "Tipo de mídia: texto”; “Categoria: teses e dissertações” }\end{array}$ \\
\hline
\end{tabular}

"available at www.dominiopublico.gov.br (only in Portuguese) performed independently by three researchers (SDF, MTS, MFRST). The references of the articles selected were evaluated to identify further published papers. Decisions concerning the inclusion or exclusion of articles were made jointly by all the researchers.

\section{Appraisal of the articles, data extraction and analysis}

The articles selected were fully analyzed by two researchers (MTS, MFRST). The quality was evaluated on the basis of eight criteria, each yielding a score of zero or one. ${ }^{5}$ In this methodological scoring system for rating the studies, use of the following criteria received scores of one: (i) random sample or whole population; (ii) unbiased sampling frame (i.e. census data); (iii) adequate sample size (> 300 subjects); (iv) standard measurements; (v) outcomes measured by unbiased assessors; (vi) adequate response rate $(>70 \%)$ and subjects described as refusing treatment; (vii) confidence intervals and subgroup analysis; and (viii) study subjects described. The total score achieved could vary from zero (poor quality) to eight (high quality). Two researchers (SDF, MTS) recorded the contents of each selected article in a structured file that included: (i) names of the authors, year of publication and location of study; (ii) sample type; (iii) population characteristics; (iv) size of population; (v) screening tools; (vi) evaluators' background; (vii) occurrence of sample losses; (viii) prevalence rates of dementia and corresponding confidence intervals (95\%); and (ix) sociodemographic characteristics of the population. We performed meta-analysis to pool the individual studies estimates and meta-regression to assess heterogeneity, both with random effects models, using the Meta-Analyst software. ${ }^{6}$

\section{RESULTS}

A total of 112 articles were identified through the online search, and eighteen ${ }^{1,7-23}$ were selected and fully analyzed (Figure 1). Only eight articles $^{7-14}$ complied with the inclusion and exclusion criteria. Three additional papers ${ }^{24-26}$ were identified from the references. Five articles $s^{7,10,11,18,26}$ attained high-quality scores, according to the criteria adopted ( $\geq 6$ points). The dementia rates reported in these five high-quality papers ranged from 5.1 to $19.0 \%$ (Table 2). A visual inspection of the meta-analysis suggested that there was high heterogeneity between the study results (Figure 2A). The meta-regression indicated that the

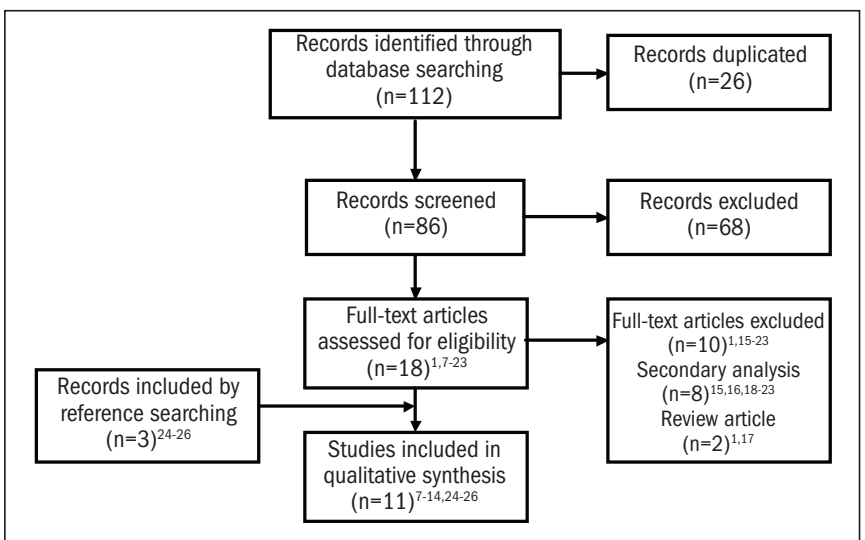

Figure 1. Fluxogram showing the process of article selection 
Table 2. Details of studies selected for the systematic review on the prevalence of dementia among elderly populations in Brazil

\begin{tabular}{|c|c|c|c|c|c|c|}
\hline First author and year published & Location & Subjects & Urban/rural & Screening and/or criterion tools & Prevalence $(95 \% \mathrm{Cl})$ & Quality score \\
\hline \multicolumn{7}{|c|}{ High-quality studies } \\
\hline Herrera Jr., ${ }^{23}$ & Catanduva (SP) & 1,656 & $\mathrm{U}$ & MMSE; PFAQ; DSM-IV & $7.1(6.0-8.5)$ & 6 \\
\hline Lebrão e Laurenti'i ${ }^{26,}$ & São Paulo (SP) & 2,143 & U & MMSE; PFAQ; GDS & $6.9(5.9-8.1)$ & 7 \\
\hline Scazufca et al., ${ }^{10}$ & São Paulo (SP) & 2,072 & $\mathrm{U}$ & CSI-D; CERAD; GMS; HAS-DDS; DSM-IV & $5.1(4.2-6.1)$ & 8 \\
\hline Bottino et al.., ${ }^{7}$ & São Paulo (SP) & 1,563 & U & MMSE; FOME; IQCODE; B-ADL & $16.0(14.3-17.9)$ & 7 \\
\hline \multicolumn{7}{|c|}{ Moderate-quality studies } \\
\hline Magalhães et al., ${ }^{8}$ & Santo Estevão (BA) & 466 & $\mathrm{R}$ & CAMDEX; CAMCOG & $49.6(45.0-54.1)$ & 5 \\
\hline Benedetti et al., ${ }^{9}$ & Florianópolis (SC) & 875 & $\mathrm{U}$ & BOAS; IPAQ & $13.8(11.7-16.3)$ & 5 \\
\hline \multicolumn{7}{|c|}{ Poor-quality studies } \\
\hline Ramos-Cerqueira et al., ${ }^{24}$ & Pirajú (SP) & 2,222 & U & DSM-IV & $2.0(1.5-2.7)$ & 3 \\
\hline Teixeira et al., ${ }^{14}$ & Caeté (MG) & 639 & $\mathrm{U} / \mathrm{R}$ & MMSE; PFAQ; GDS; MINI; DSM-IV & $27.5(24.2-31.1)$ & 3 \\
\hline
\end{tabular}

Dementia reported as cognitive impairment; $\mathrm{Cl}=$ confidence interval; $\mathrm{U}=$ urban; $\mathrm{R}=$ rural; $\mathrm{MMSE}=$ Mini Mental State Examination; FOME = Fuld Object Memory Evaluation; IQCODE = Informant Questionnaire on Cognitive Decline in the Elderly; B-ADL = Bayer-Activities of Daily Living scale; CAMDEX = Cambridge Examination for Mental Disorders; $C A M C O G=$ cognitive section of CAMDEX; BOAS = Brazil Old Age Schedule; IPAQ = International Physical Activity Questionnaire; CSI-D = Community Screening Instrument for Dementia; CERAD = Consortium to Establish a Registry for Alzheimer's Disease; GMS = Geriatric Mental State; HAS-DDS = History and Aetiology Schedule Dementia Diagnosis and Subtype; DSM-IV = Diagnostic and Statistical Manual of Mental Disorders, 4th edition; PFAQ = Pfeffer Functional Activities Questionnaire; GDS = Geriatric Depression Scale; MINI = Mini International Neuropsychiatric Interview.

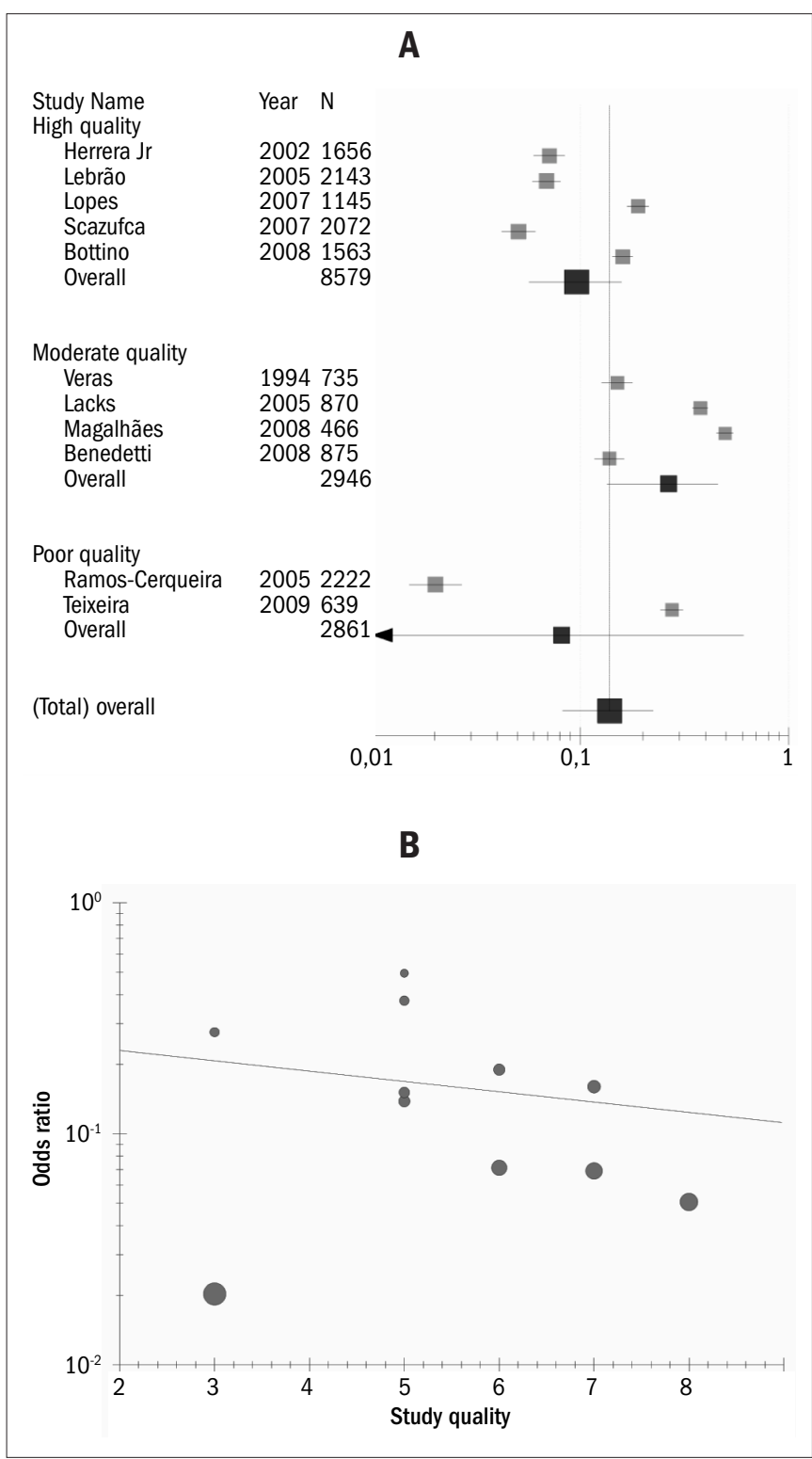

Figure 2. Meta-analysis (A) and meta-regression (B) on studies included prevalence was overestimated in the low-quality studies (Figure 2B). Because of this heterogeneity, we did not take the pooled data any further. The prevalence of dementia increased with age and was inversely related to the socioeconomic status and number of years of education (Table 3 ). Prevalence rates were higher among women.

\section{DISCUSSION}

The present review presents an attempt to describe the prevalence of dementia among the elderly population in Brazil, derived from highquality research papers.

Dementia rates have been determined in non-representative sample populations in which subjects were chosen according to opportunity and recruited from meeting places such as charity organizations and geriatric clinics. Studies based on such convenience populations were not taken into consideration in the present review, since the rates found have shown wide variability caused by selection bias. The rates in one systematic review ${ }^{27}$ ranged from 0.7 to $70.2 \%$. For this reason, the present review only included population-based studies. A further limitation of many published studies relates to the size of the sample population, which may include as few as 40 participants. ${ }^{27}$ One criterion used in the present review was that for a study to be included, it should have a minimum of 300 participants.

Despite the high quality of the articles selected for this review, there were methodological disparities between them. For instance, the articles differed with regard to the age range of the population selected for the study. The age distribution in the sample population could affect the results, since in locations with a large number of individuals $>80$ years old, the prevalence of dementia would probably be higher. The non-uniform age distribution of the sample populations considered in the studies reviewed may explain the variation in the prevalence of dementia that was detected. Similar assumptions may be made in relation to gender-based and socioeconomic status-based distributions, i.e. the prevalence of dementia is probably higher in populations that encompass large numbers of poor elderly women. 
Table 3. Percentage of dementia among elderly populations in Brazil, distributed according to sociodemographic characteristics of the sample populations

\begin{tabular}{|c|c|c|c|c|c|c|c|c|c|c|c|}
\hline \multirow[b]{3}{*}{ Characteristics evaluated } & \multicolumn{11}{|c|}{ Reference } \\
\hline & \multicolumn{5}{|c|}{ High-quality studies } & \multicolumn{4}{|c|}{ Moderate-quality studies } & \multicolumn{2}{|c|}{ Poor-quality studies } \\
\hline & $\begin{array}{l}\text { Herrera Jr. } \\
\text { et al.,, } 13,23\end{array}$ & $\begin{array}{l}\text { Lebrão } \\
\text { et al.., } 4,27\end{array}$ & $\begin{array}{l}\text { Lopes } \\
\text { et al.,"11 }\end{array}$ & $\begin{array}{l}\text { Scazufca } \\
\text { et al., }{ }^{10}\end{array}$ & $\begin{array}{l}\text { Bottino } \\
\text { et al., }{ }^{7}\end{array}$ & $\begin{array}{c}\text { Veras e } \\
\text { Murphy }{ }^{25}\end{array}$ & $\begin{array}{l}\text { Lacks } \\
\text { et al., }{ }^{12}\end{array}$ & $\begin{array}{l}\text { Magalhães } \\
\text { et al., }\end{array}$ & $\begin{array}{l}\text { Benedetti } \\
\text { et al., }{ }^{9}\end{array}$ & $\begin{array}{l}\text { Ramos- } \\
\text { Cerqueira } \\
\text { et al., }{ }^{24}\end{array}$ & $\begin{array}{l}\text { Teixeira } \\
\text { et al., }{ }^{14}\end{array}$ \\
\hline \multicolumn{12}{|l|}{ Age (years) } \\
\hline $60-64$ & NR & 3.6 & 10.6 & NR & 2.5 & 1.1 & NR & 44.0 & NR & NR & NR \\
\hline $65-69$ & 1.6 & 3.3 & 12.4 & 2.2 & 4.1 & & & & & 0.1 & \\
\hline $80-84$ & 15.1 & 19.5 & 40.7 & 13.6 & 13.3 & 3.2 & & 53.4 & & 3.1 & \\
\hline $85-89$ & 38.9 & 31.6 & 64.7 & 21.4 & 15.3 & & & & & 12.0 & \\
\hline$\geq 90$ & & & 66.7 & & 42.3 & & & 86.7 & & & \\
\hline \multicolumn{12}{|l|}{ Gender } \\
\hline Female & 9.4 & 7.5 & 25.2 & 5.4 & 7.3 & 1.7 & 43.6 & 50.2 & 17.8 & 2.2 & NR \\
\hline $5-8$ & & 5.5 & 21.1 & & 2.7 & & 21.7 & & & & \\
\hline $1-4$ & & & 26.6 & & 6.7 & & & & & & \\
\hline 0 & 12.2 & 16.8 & 42.5 & & 18.7 & & 62.8 & 45.8 & & & \\
\hline \multicolumn{12}{|l|}{ Socioeconomic status } \\
\hline A & 5.4 & NR & 15.0 & NR & 2.9 & NR & NR & NR & NR & NR & NR \\
\hline$B$ & 7.2 & & 14.6 & & 5.2 & & & & & & \\
\hline C & 7.0 & & 22.8 & & 5.1 & & & & & & \\
\hline D & 6.7 & & 32.1 & & 10.7 & & & & & & \\
\hline $\mathrm{E}$ & 10.9 & & 41.3 & & 15.8 & & & & & & \\
\hline
\end{tabular}

NR $=$ not reported.

All the high-quality studies analyzed had been conducted in the State of São Paulo, in southeastern Brazil, an area that occupies a unique position in terms of development and living standards. Therefore, the findings regarding the prevalence of dementia cannot be generalized to other Brazilian regions. All of these five studies involved application of two or more validated screening tools. Although the use of different tests may improve the precision of the results, the possibility of divergence between evaluators is increased and the results may be distorted.

The prevalence of dementia in developing countries is often estimated from statistics from different locations, because of the lack or imprecision of local data. In developed countries, the prevalence of dementia apparently doubles for every five-year increase in age, and it typically varies from $3 \%$ at 70 years of age to $20-30 \%$ at 85 years of age. ${ }^{1}$ The results reviewed here suggest that the prevalence of dementia in the State of Sáo Paulo is roughly compatible with that of many developed countries.

Canada presents one of the lowest rates of dementia in the world, with a prevalence of $4.2 \%$ among individuals $\geq 65$ years of age. ${ }^{28}$ This relatively low incidence of the disease may be explained by a number of factors, including the existence of a first-class health system, the high quality of life among the elderly population, encouragement towards intellectual activities and the superior quality of research. In one of the Brazilian high-quality studies, the prevalence of dementia was lower than in Canada, in contrast to the other studies. The reason for the discrepancy between these studies is unclear, but may indicate a lack of standardization in the methodology used.

\section{CONCLUSIONS}

Dementia was most prevalent among poor, illiterate, female and very elderly individuals. The overall prevalence of dementia among elderly Brazilians could not be estimated because of the wide variations reported. The studies reviewed may reflect the situation of southeastern Brazil and not the reality of the whole country. Methods with greater consistency should be used in clinical and epidemiological studies in order to assess the real extent of the problem of dementia in Brazil.

\section{REFERENCES}

1. Scazufca M, Cerqueira ATAR, Menezes PR, et al. Investigações epidemiológicas sobre demência nos países em desenvolvimento [Epidemiological research on dementia in developing countries]. Rev Saúde Pública = J Public Health. 2002;36(6):773-8.

2. Pereira MG, Rebouças M. Indicadores de saúde para idosos. In: Freitas EV, Py L, Neri AL, et al, editors. Tratado de geriatria e gerontologia. Rio de Janeiro: Guanabara-Koogan; 2008. p. 131-9.

3. Rebouças M, Pereira MG. Indicadores de saúde para idosos: comparação entre o Brasil e os Estados Unidos [Health indicators in the elderly: a comparison of Brazil and the United States]. Rev Panam Salud Pública = Pan Am J Public Health. 2008;23(4):237-46.

4. Lebrão ML, Duarte YAO. 0 projeto SABE no município de São Paulo: uma abordagem inicial. Brasília: Organização Pan-Americana da Saúde; 2003.

5. Loney PL, Chambers LW, Bennett K, Roberts JG, Stratford PW. Critical appraisal of the health research literature: prevalence or incidence of a health problem. Chronic Dis Can. 1998;19(4):170-6.

6. Wallace BC, Schmid CH, Lau J, Trikalinos TA. Meta-Analyst: software for meta-analysis of binary, continuous and diagnostic data. BMC Med Res Methodol. 2009;9:80.

7. Bottino CM, Azevedo D Jr, Tatsch M, et al. Estimate of dementia prevalence in a community sample from São Paulo, Brazil. Dement Geriatr Cogn Disord. 2008;26(4):291-9. 
8. Magalhães MOC, Peixoto JMS, Frank MH, et al. Fatores de risco para demência em uma área rural do nordeste do Brasil [Risk factors for dementia in a rural area of Northeastern Brazil]. Arq Neuropsiquiatr. 2008;66(2a):157-62.

9. Benedetti TRB, Borges L, Petroski EL, Gonçalves LHT. Atividade física e estado de saúde mental de idosos [Physical activity and mental health status among elderly people]. Rev Saude Publica = J Public Health. 2008;42(2):302-7.

10. Scazufca M, Menezes PR, Vallada HP, et al. High prevalence of dementia among older adults from poor socioeconomic backgrounds in São Paulo, Brazil. Int Psychogeriatr. 2008;20(2):394-405.

11. Lopes MA, Hototian SR, Bustamante SE, et al. Prevalence of cognitive and functional impairment in a community sample in Ribeirão Preto, Brazil. Int J Geriatr Psychiatry. 2007;22(8):770-6.

12. Laks J, Batista EMR, Guilherme ERL, et al. Prevalence of cognitive and functional impairment in community-dwelling elderly: importance of evaluating activities of daily living. Arq Neuropsiquiatr. 2005;63(2a):207-12.

13. Herrera JrE, Caramelli P, Silveira AS, Nitrini R. Epidemiologic survey of dementia in a community-dwelling Brazilian population. Alzheimer Dis Assoc Disord. 2002;16(2):103-8.

14. Teixeira AL, Caramelli P, Barbosa MT, et al. Prevalence of major psychiatric disorders in a cohort of oldest old in Brazil: The Pietà study. Alzheimer's \& Dementia: The Journal of the Alzheimer's Association. 2009;5(4):P392. Available from: http://www.alzheimersanddementia.com/article/S1552-5260(09)00905-4/abstract. Accessed in 2010 (Oct 15)

15. Benseñor IM, Lotufo PA, Menezes PR, Scazufca M. Subclinical hyperthyroidism and dementia: the Sao Paulo Ageing \& Health Study (SPAH). BMC Public Health. 2010;10:298.

16. Lopes MA, Furtado EF, Ferrioli E, Litvoc J, Bottino CM. Prevalence of alcohol-related problems in an elderly population and their association with cognitive impairment and dementia. Alcohol Clin Exp Res. 2010;34(4):726-33.

17. Nitrini R, Bottino CM, Albala C, et al. Prevalence of dementia in Latin America: a collaborative study of population-based cohorts. Int Psychogeriatr. 2009;21(4):622-30.

18. Coutinho LM, Scazufca M, Menezes PR. Métodos para estimar razão de prevalência em estudos de corte transversal [Methods for estimating prevalence ratios in crosssectional studies]. Rev Saúde Pública = J Public Health. 2008;42(6):992-8.

19. Scazufca M, Menezes PR, Araya R, et al. Risk factors across the life course and dementia in a Brazilian population: results from the Sao Paulo Ageing \& Health Study (SPAH). Int J Epidemiol. 2008;37(4):879-90.

20. Scazufca M, Almeida OP, Vallada HP, Tasse WA, Menezes PR. Limitations of the MiniMental State Examination for screening dementia in a community with low socioeconomic status: results from the Sao Paulo Ageing \& Health Study. Eur Arch Psychiatry Clin Neurosci. 2009;259(1):8-15.

21. Tatsch MF, Bottino CM, Azevedo D, et al. Neuropsychiatric symptoms in Alzheimer disease and cognitively impaired, nondemented elderly from a community-based sample in Brazil: prevalence and relationship with dementia severity. Am J Geriatr Psychiatry. 2006;14(5):438-45.

22. Ribeiz SRI, Bassitt DP, Litvoc J, Bottino CMC. Psychotic symptoms in the elderly: Prevalence in Alzheimer's disease and nondemented individuals from a community-based sample in Brazil. [abstract P2-117] Alzheimer's \& Dementia: The Journal of the Alzheimer's Association. 2009;5(4 Supplement):P296. Available from: http://download.journals. elsevierhealth.com/pdfs/journals/1552-5260/PIIS1552526009005007.pdf. Accessed in 2010 (Oct 15).

23. Herrera Junior E, Caramelli P, Nitrini R. Estudo epidemiologico populacional de demencia na cidade de Catanduva, estado de São Paulo, Brasil [Population epidemiologic study of dementia in Catanduva city: state of Sao Paulo, Brazil]. Rev Psiquiatr Clín (São Paulo). 1998;25(2):70-3.

24. Ramos-Cerqueira AT, Torres AR, Crepaldi AL, et al. Identification of dementia cases in the community: a Brazilian experience. J Am Geriatr Soc. 2005;53(10):1738-42.

25. Veras RP, Murphy E. The mental health of older people in Rio de Janeiro. International Journal of Geriatric Psychiatry. 1994;9(4):285-95. Available from: http://onlinelibrary wiley.com/doi/10.1002/gps.930090405/abstract. Accessed in 2010 (0ct 15).

26. Lebrão ML, Laurenti R. Saúde, bem-estar e envelhecimento: o estudo SABE no município de São Paulo [Health, well-being and aging: the SABE study in São Paulo, Brazil] Rev Bras Epidemiol. 2005;8(2):127-41.

27. Lopes MA. Revisão sistemática dos estudos de prevalência de demência: período de 1994 a 2000. [dissertation]. São Paulo: Faculdade de Medicina da Universidade de São Paulo; 2002.

28. McDowell I, Hill G, Lindsay J. Canadian study of health and aging: study methods and prevalence of dementia. CMAJ. 1994;150(6):899-913.
Conflict of interest: None

Sources of funding: None

Date of first submission: March 10, 2010

Last received: October 29, 2010

Accepted: November 3, 2010

Address for correspondence:

Marcus Tolentino Silva

Esplanada dos Ministérios - bloco G

Ministério da Saúde, Edifício Sede - sala 852

Zona Cívico-Administrativa

Brasília (DF) - Brasil

CEP 70058-900

Tel. (+55 61) 33153858

E-mail: marcus.silva@saude.gov.br 